Revista do Programa de Pós-Graduação em Artes da

Cena, Universidade Estadual de Campinas

Performing Arts Graduate Program Journal, University of

Campinas

\title{
Ensino de dança em tempos de resistência (Editorial)
}

\author{
Dance teaching in times of resistance (Editorial)
}

\section{Ana Maria Rodriguez Costas (Ana Terra) ${ }^{1}$ Mariana Baruco Machado Andraus ${ }^{2}$}

A Conceição/Conception torna pública uma edição especial dedicada ao ensino de dança, especialmente, em um cenário marcado por alterações legislativas no que tange ao seu entendimento não mais como área de conhecimento independente, mas como conteúdo a ser trabalhado de forma transversal por professores sem formação específica, o que representa um enorme retrocesso em termos educacionais. Quando se entende o ser humano em sua integridade, promover um relacionamento sensível com o próprio corpo e com sua capacidade de expressão - que pode se revelar (e historicamente se revela) por meio da arte - é competência necessária à formação do indivíduo não somente quando ele vem a optar pelo trabalho como artista da dança, mas também em outras profissões.

Em evento ocorrido em abril de 2017, um conhecido deputado federal colocou em questão a lei $\mathrm{n}^{\circ} 13.278 / 2016$, aprovada por Dilma Rousseff, que reforça na LDB a obrigatoriedade do ensino das quatro linguagens na disciplina Arte. Referindo-se especificamente à dança, ele condenou sua presença no contexto escolar

\footnotetext{
${ }_{1}^{1}$ Universidade Estadual de Campinas. Professora do Programa de Pós-Graduação em Artes da Cena e dos Cursos de Bacharelado e Licenciatura em Dança. ORCID: https://orcid.org/0000-0002-40884838 Contato: anaterradanza@gmail,com

2 Universidade Estadual de Campinas. Professora do Programa de Pós-Graduação em Artes da Cena e dos Cursos de Bacharelado e Licenciatura em Dança. ORCID: https://orcid.org/0000-0003-44608555 Contato: mandraus@g.unicamp.br
}

\begin{tabular}{l|l|l|l|l}
\hline (C) Conceição | Conception & Campinas, SP & Edição Especial & p. 01-02 & out./out. 2018 \\
\hline
\end{tabular}


Conceição | Conception

Revista do Programa de Pós-Graduação em Artes da

Cena, Universidade Estadual de Campinas

Performing Arts Graduate Program Journal, University of

Campinas

argumentando que a intenção seria, talvez, propiciar aos alunos dançar a dança da "Boquinha da Garrafa".

Sem entrar em julgamento sobre o que deve ou não ser dançado, considerando a importância da diversidade de danças em nosso país - tradicional, popular, clássica, moderna, contemporânea - o ensino da dança na escola tem uma longa trajetória (mesmo que sempre ameaçada) muito distinta da mera reprodução de danças veiculadas pela cultura do entretenimento. Por essa razão, trazemos aos leitores os artigos deste fascículo especial, que apresentam relatos de experiências e reflexões relacionadas ao ensino de dança tanto na escola quanto em ambientes não formais de ensino, abordando a dança quanto ao seu potencial de empoderamento e desenvolvimento da sensibilidade, de construção da autonomia, de estímulo à sociabilidade, desde a infância até a adolescência, a fase adulta e a senilidade, de forma inclusiva, democrática e socialmente referenciada.

Os artigos são de autoria de professoras permanentes do Programa de PósGraduação em Artes da Cena da Unicamp que são também orientadoras dos cursos de graduação em Dança da universidade (Bacharelado e Licenciatura), em coautoria com professoras de dança licenciadas pelo curso da Unicamp, em uma parceria entre pós-graduação e graduação alinhavada pelas pesquisas de docentes nos campos artístico e pedagógico da dança.

Informamos que o vol. 7 n. 2 será publicado normalmente dentro dos prazos regulares. Em um momento de tantas incertezas, este fascículo foi proposto em caráter excepcional, com o intuito de esclarecimento social sobre a importância da arte e, particularmente, da arte da dança, no âmbito da educação brasileira. Esperamos que as experiências e reflexões que compõem este número possam contribuir com a luta pela continuidade e ampliação do ensino de dança para todas as crianças e jovens em nosso país. 